\title{
The Effectiveness of Reflection Learning Method to Increase the First Grade Students' Writing Skill of SMA Negeri 2 Sungguminasa Gowa Regency
}

\section{Musdalifah, Musdalifah}

English Education Department, STKIP Muhammadiyah Enrekang, South Sulawesi-Indonesia

\section{ARTICLE INFO}

Article History:

Received 11 December 2018

Accepted 21 January 2019

\begin{abstract}
This research consisted of two objectives research, first objective research that was to find out the students' increased of content of writing recount text by using reflection learning method at the first grade students of SMA Negeri 2 Sungguminasa Gowa Regency, and second objective research that was to find out the students' increased of organization of writing recount text by using reflection learning method at the first grade students of SMA Negeri 2 Sungguminasa Gowa Regency. There were of assessment focused on the skill of students to write a recount text from content which consisted of unity, and completeness; organization which consisted of coherence, and spatial order; and generic structures which consisted of orientation, events, and reorientation. This research applied Classroom Action Research (CAR) design which divided into two cycles (cycle I and cycle II) and consisted of four stages or phases (planning, implementation of action, observation, and reflection). The subject of this research that was students of class $X$ which consisted of 33 students. The instrument of this research that was writing test which it used recount text. The test would be used in the last item of every cycle. Moreover, based on the students' score in cycle I and cycle II, it showed that the score of students is increased from the standard score 7.00 with the significant increased $47.27 \%$.
\end{abstract}

\section{INTRODUCTION}

Writing is form of communication through which people can express their idea, feeling and knowledge. Writing is considered the most difficult to be learned and mastered because it involves some language components such as spelling, language use, vocabulary, and punctuation (Zubizarreta, 2016:126).

Based on the problems in the preliminary observation on $25^{\text {th }}$ October 2016 in the teaching and learning process at SMA Negeri 2 Sungguminasa Gowa South

@Majesty Journal 2019

$\triangle$ Corresponding author:

Address : STKIP Muhammadiyah Enrekang

Email : musdalifah_ifahrahman@yahoo.com
Published by STKIP Muhammadiyah Enrekang ISSN 2567-0157 (Online) 
Sulawesi, the writer found that there was specific problem or difficulty in writing skill. It can be seen from the result of the students in preliminary observation activity that was 4.50 , and it means that the score is still poor from the target score that was 7.00. To decrease the problems in writing skill, the writer (teacher) needs to apply the interested method that was reflection learning method. Therefore, the writer is interested to create or perform a research that under title "The Effectiveness of Reflection Learning Method to Increase the First Grade Students' Writing Skill of SMA Negeri 2 Sungguminasa Gowa Regency".

\section{REVIEW OF RELATED LITERATURE}

\section{Reflection Learning Method}

Keogh and Walker (2016: 7-15) stated that reflection learning method is a type of learning and teaching method that can be a in individual and group work. Richards and Lockhart (2016: 100-115) concluded that reflection learning method combines the three stages in the service learning process such as: pre-service, during-service, and post-service. Smith (2017: 1 - 5) explained that reflection learning method has some advantages for students and teacher in the writing learning-teaching process namely: a). It helped the students to step back and put experiences and developments into perspective, b). It made the students recognize their capacity for and enjoyment of learning, c). The students can realize that reflection is only one part of a learning experience-forming ideas and testing these are part of the learning process, and $d$ ). It helped the students to identify support for and criticism of ideas (Ismail, 2017).

\section{Writing Skill}

Oshima (2016:2) explained that writing is progress activity which it helped the students to write something down that they have already been thinking about on the paper. Writing skill had five significant components, they are content, organization, vocabulary, language usage, and mechanics (McMahan and Elizabeth, 2016:20). Andrew (2017: 10-68) concluded that there are two functions those are writing skill can be built up by giving confidence, a sense of purpose and emphasis on meaning rather than on formal accuracy, and also it can be built up by giving the students developing a firm and accurate grasp of a limited number of structures, and four steps in writing skill namely: prewriting, drafting, revising, and editing. Writing skill has two characteristics those are ideas and content, and organization (Cumming, 2016: 38).

\section{Recount Text}

Crishtopher (2017: 90) explained that recont text is a text which it retells events or experiences in the past time and it consist of scene setting (orientation), a starting point and a problem account (series of event), and a conclusion (re-orientation). The language is descriptive, and there may be dialogue (Foo, 2016:90). The main purpose or function of recount text is to retell past event or something which is happened in the past time (Djuharie, 2017:15). Recount text has some types, they are namely: personal recount, factual recount, imaginative recount, procedural recount, and biographical recount (Derewianka, 2015:35).

\section{RESEARCH METHOD}

\section{Research Design}

This research applied the Classroom Action Research (CAR). The writer divided into two cycles (cycle I and cycle II) and consisted of four stages or phases (planning, implementation of action, observation, and reflection). 


\section{Variables and Indicators}

\section{Variables}

There were two variables in this research, namely: independent variable and dependent variable.

\section{a) Independent variable}

Reflection learning method as independent variable because it gave effect on teaching and learning writing Recount text.

\section{b) Dependent variable}

The score of the first grade students of SMA Negeri 2 Sungguminasa Gowa regency in the content, organization and generic structures of writing recount text with used reflection learning method.

\section{Indicators}

There were some indicators in this research, namely:

a) The indicators of the content such as the unity and completeness.

b) The indicators of the organization such as coherence and spatial pattern.

c) The indicators of the generic structures such as orientation, events, and reorientation.

\section{Subject of Research}

a. Content

\begin{tabular}{|c|c|c|}
\hline Scores & Classifications & Criteria \\
\hline 6 & Excellent & $\begin{array}{l}\text { a. The ideas are very clearly stated. } \\
\text { b. The ideas are very clearly supported. } \\
\text { c. The ideas are very relevant. }\end{array}$ \\
\hline 5 & Very Good & $\begin{array}{l}\text { a. The ideas are clearly stated. } \\
\text { b. The ideas are clearly supported. } \\
\text { c. The ideas are relevant. }\end{array}$ \\
\hline 4 & Good & $\begin{array}{l}\text { a. The ideas are clearly stated. } \\
\text { b. The ideas are clearly supported. } \\
\text { c. The ideas are adequate relevant. }\end{array}$ \\
\hline 3 & Fair & $\begin{array}{l}\text { a. The ideas are rather clearly stated. } \\
\text { b. The ideas get enough supports. } \\
\text { c. The ideas are quite relevant. }\end{array}$ \\
\hline 2 & Poor & $\begin{array}{l}\text { a. The ideas are not clearly stated. } \\
\text { b. The ideas get limit to support. }\end{array}$ \\
\hline
\end{tabular}

The subject of this research that was the students in the first grade of SMA Negeri 2 Sungguminasa Gowa regency at the class $X$.

\section{Research Instrument}

This research used one kind of instrument namely writing test which was using recount text. The writing test would be used in the last item of every cycle to measure the students' skill in writing content and organization in recount text.

\section{Data Collections}

To collect the data would be done with the following procedures namely:

1. Data source: the data source in this research was the students' achievement in writing process before got the writing material through reflection learning method.

2. The students would be given a test. It was done after implementing the reflection learning method in the observation stage of classroom action research (CAR) which would be done in every cycle.

3. To measured 3 components in writing proficiency, the writer used the following rating scale: 


\begin{tabular}{lll}
\hline & c. The ideas are not quite relevant. \\
\hline 1 & Very Poor & a. The ideas are not clearly stated. \\
& b. The ideas are not clearly supported. \\
& c. The ideas are irrelevant.
\end{tabular}

(Virginia, 2016: 120)

b. Organization

\begin{tabular}{|c|c|c|}
\hline Scores & Classifications & Criteria \\
\hline 6 & Excellent & $\begin{array}{l}\text { a. Clear and logical progression of ideas. } \\
\text { b. Strong beginning, middle, and end. } \\
\text { c. Strong use of transition. }\end{array}$ \\
\hline 5 & Very Good & $\begin{array}{l}\text { a. Logical progression of ideas. } \\
\text { b. Clear beginning, middle, and end. } \\
\text { c. Sufficient use of transition. }\end{array}$ \\
\hline 4 & Good & $\begin{array}{l}\text { a. Some evidence of a logical progression of ideas. } \\
\text { b. Clear beginning, middle, and end. } \\
\text { c. Some use of transition. }\end{array}$ \\
\hline 3 & Fair & $\begin{array}{l}\text { a. Limited evidence of a progression of ideas. } \\
\text { b. Clear beginning, middle, and end. } \\
\text { c. Limited use of transition. }\end{array}$ \\
\hline 2 & Poor & $\begin{array}{l}\text { a. Lacks evidence of a logical progression of ideas. } \\
\text { b. Lacks a beginning, middle, and/or end. } \\
\text { c. Lacks clear transition. }\end{array}$ \\
\hline 1 & Very Poor & $\begin{array}{l}\text { a. Little progression of ideas, difficult to follow. } \\
\text { b. Little evidence of beginning, middle or end. } \\
\text { c. Little transition. }\end{array}$ \\
\hline
\end{tabular}

(Virginia, 2016: 121)

\section{c. Generic Structures}

\begin{tabular}{|c|c|c|c|}
\hline Indicators & Criteria & Classifications & Score \\
\hline \multirow{5}{*}{ Orientation } & $\begin{array}{l}\text { Very complete in introducing the personal } \\
\text { participation, location time, organizations, } \\
\text { grammar and mechanics, sentence } \\
\text { structure. }\end{array}$ & Excellent & 6 \\
\hline & $\begin{array}{l}\text { Complete in introducing the personal } \\
\text { participation, location and time, } \\
\text { organizations, grammar and mechanics, } \\
\text { sentence structure. }\end{array}$ & Very Good & 5 \\
\hline & $\begin{array}{l}\text { Enough to introduce the personal } \\
\text { participation, location and time enough. } \\
\text { Adequate in organizations, grammar and } \\
\text { mechanics, sentence structure. }\end{array}$ & Good & 4 \\
\hline & $\begin{array}{l}\text { Incomplete to introduce the personal } \\
\text { participation, location and time, } \\
\text { organizations, grammar and mechanics, } \\
\text { sentence structure }\end{array}$ & Fair & 3 \\
\hline & $\begin{array}{l}\text { Indigent in introducing the personal } \\
\text { participation, place and time, } \\
\text { organizations, grammar and mechanics, }\end{array}$ & Poor & 2 \\
\hline
\end{tabular}




\begin{tabular}{|c|c|c|c|}
\hline & \multicolumn{3}{|l|}{ sentence structure. } \\
\hline & No answer in introducing. & Very Poor & 1 \\
\hline \multirow[t]{6}{*}{ Events } & $\begin{array}{l}\text { Very complete to introduce the series of } \\
\text { events, organizations, grammar and } \\
\text { mechanics, sentence structure. }\end{array}$ & Excellent & 6 \\
\hline & $\begin{array}{l}\text { Complete to introduce the series of events, } \\
\text { organizations, grammar and mechanics, } \\
\text { sentence structure. }\end{array}$ & Very Good & 5 \\
\hline & $\begin{array}{l}\text { Enough to introduce the series of events, } \\
\text { organizations, grammar and mechanics, } \\
\text { sentence structure. }\end{array}$ & Good & 4 \\
\hline & $\begin{array}{l}\text { Incomplete to introduce the series of } \\
\text { events, organizations, grammar and } \\
\text { mechanics, sentence structure. }\end{array}$ & Fair & 3 \\
\hline & $\begin{array}{l}\text { Indigent to introduce the series of events, } \\
\text { organizations, grammar and mechanics, } \\
\text { sentence structure. }\end{array}$ & Poor & 2 \\
\hline & No answer in events & Very Poor & 1 \\
\hline \multirow[t]{6}{*}{$\begin{array}{c}\mathrm{Re}- \\
\text { orientation }\end{array}$} & $\begin{array}{l}\text { Very complete explains the writer's opinion } \\
\text { or comments about the story, } \\
\text { organizations, grammar and mechanics, } \\
\text { sentence structure. }\end{array}$ & Excellent & 6 \\
\hline & $\begin{array}{l}\text { Complete explains the writer's opinion or } \\
\text { comments about the story, organizations, } \\
\text { grammar and mechanics, sentence } \\
\text { structure. }\end{array}$ & Very Good & 5 \\
\hline & $\begin{array}{l}\text { Enough to explain the writer's opinion or } \\
\text { comment about the story, organizations, } \\
\text { grammar and mechanics, and sentence } \\
\text { structure. }\end{array}$ & Good & 4 \\
\hline & $\begin{array}{l}\text { Incomplete explains the writer's opinion or } \\
\text { comment about the story, organizations, } \\
\text { grammar and mechanics, sentence } \\
\text { structure. }\end{array}$ & (Harimer & 1316) \\
\hline & $\begin{array}{l}\text { Indigent to explain the writer's opinion or } \\
\text { comment to the story, organizations, } \\
\text { grammar and mechanics, sentence } \\
\text { structure. }\end{array}$ & Poor & 2 \\
\hline & No answer in giving comments. & Very Poor & 1 \\
\hline
\end{tabular}

\section{Data Analysis}

(V(Virginia, 2016: 122)

The data were got from cycle I and cycle II were analyzed through the followed steps:

a. To found the score of each student, the writer used the following formula: 


$$
\text { Students Score }=\frac{\text { The Number of student's corret answer }}{\text { the total score }} \times 10
$$

(Gay, 2016: 298)

b. To calculated the mean score of the students' test result. The writer was using formula:

$$
\begin{aligned}
& \mathrm{X}=\frac{\sum X}{N} \\
\text { Where: } \quad \mathrm{X} & =\text { Mean score } \quad \sum X=\text { the total score } \\
N & =\text { the total number of students }
\end{aligned}
$$

(Gay, 2016: 300)

c. To knew the percentage of students' improvement by applying the following formula:

$$
\mathbf{P}=\frac{\mathbf{X}_{2}-\mathbf{X}_{1}}{\mathbf{X}_{1}} \times \mathbf{1 0 0}
$$

Where: $P=$ Percentage $\quad X 2=$ the second mean score

$$
\mathrm{X} 1=\text { The first mean score } \quad \text { (Gay, 2016: 300) }
$$

d. To calculated percentage students' achievement in the content, organization, and generic structures writer used the formula:

$$
\mathbf{P}=\frac{\mathbf{F}}{\mathrm{N}} \times \mathbf{1 0 0}
$$

$$
\text { Where: } \begin{aligned}
\mathrm{P} & =\text { Percentage } \quad \mathrm{N}=\text { Total Number of Subject } \\
& \mathrm{F}=\text { Frequency }
\end{aligned}
$$

(Gay, 2016: 301)

e. To analyzed the students' activeness in the material and activities in taught and learned processed by checklist. The students' activeness described followed:

\begin{tabular}{cccl}
\hline No & $\begin{array}{c}\text { The Students' Active } \\
\text { Participation }\end{array}$ & Scores & Indicators \\
\hline 1. & Very Active & 4 & Students' respond the material very active. \\
\hline 2. & Active & 3 & Students' respond to the material actively. \\
\hline 3. & Fairly Active & 2 & Students' respond to the material just one or twice. \\
\hline 4. & Not Active & 1 & $\begin{array}{l}\text { Students just sit down during the activity without } \\
\text { doing something. }\end{array}$ \\
\hline
\end{tabular}

(Weigle, 2016: 116)

Percentage the students' participation through the followed formula:

Where:

$$
P=\frac{F q}{4 \times N} \times 100
$$

$$
\begin{aligned}
& \mathrm{P}=\text { Percentage. } N=\text { the Total of Students. } \\
& \mathrm{Fq}=\text { Sum of All the Students' Score } \\
& \text { (Gay, 2016: 302) }
\end{aligned}
$$

d. From the basic standard above the writer formulates the standard score for the total value of the students' writing by calculating the standard score given, as follows:

1. Scores 9.0-10 is classified as excellent. 2.Scores 8.0-8.9 is classified as very good.

3. Scores 7.0- 7.9 is classified as good. $\quad 4$. Scores 6.0-6.9 is classified as fairly.

5. Scores 5.0-5.9 is classified as poor. $\quad 6 . S c o r e ~ 0-4.9$ is classified as very poor.

(Harmer, 2017: 116) 


\section{Research Findings and Discussions}

\section{Research Findings}

The findings of the research deal with the answer of the problem statement and the score of the students in learning writing skill with covers terms "content, organization, and generic structures" through reflection learning method at the first grade students of SMA Negeri 2 Sungguminasa Gowa regency.

\section{a. The Increasing Score of Students'} Recount Text through Reflection Learning Method from Its Contents with indicators "Unity and Completeness"

The score of the students' writing skill in recount text for content with indicators "unity and completeness" indicate that there is increasing between score in cycle I and cycle II after use one method that is reflection learning method. The increasing score of students' recount text through reflection learning method from its contents shows in table 1.

Table 1: The Increasing Score of Students' Recount Text through Reflection Learning Method from Its Contents with indicators "Unity and Completeness"

\begin{tabular}{|c|c|c|c|c|}
\hline \multirow{2}{*}{ NO } & \multirow{2}{*}{ Indicators } & \multicolumn{2}{|c|}{ The Student' Score } & Increasing \\
\cline { 2 - 5 } & & Cycle I & Cycle II & CI - CII (\%) \\
\hline $\mathbf{1}$ & Unity & 5.21 & 7.13 & 36.85 \\
\hline $\mathbf{2}$ & Completeness & 5.52 & 7.92 & 43.48 \\
\hline & $\sum \boldsymbol{X}$ & 10.73 & 15.05 & 80.33 \\
\hline & $\bar{X}$ & 5.37 & 7.53 & 40.17 \\
\hline
\end{tabular}

The data of table 1 indicates the students' mean score from content with indicators "unity and completeness" in cycle I are 5.37 and classifies as poor score. Through revision of the lesson plan to be implemented in learning process, the target has been achieved with the mean score over 7.0 that are 7.53 with some corrections of activities in the cycle II. The mean score in data of table 1 achieves by the students in cycle II has been indicated a significant increasing in term of recount text that it $40.17 \%$ from cycle I to cycle II. The increasing of the students' recount text through reflection learning method in the contents presents at the figure 1 .
Figure 1: The Increasing of Students' Recount Text through Reflection Learning Method from Its Contents

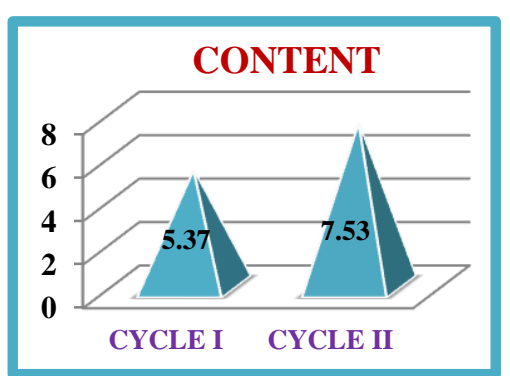

The data of the figure 1 indicates the students' recount text achievement is on the cycle I. The students' recount text achievement in cycle II is higher than cycle I that is $7.53>5.37$. The cycle I means that the 
score increasing in cycle II, with the increasing from cycle I to cycle II is $40.79 \%$.

b. The Increasing Score of Students' Recount Text through Reflection Learning Method from Its Organizations with Indicators "Coherence and Spatial Order"
The score of the students' writing skill in recount text for organization with indicators "coherence and spatial order" indicates that there is increasing between score in cycle I and cycle II after use one method that is reflection learning method. The increasing score of students' recount text through reflection learning method from its organizations shows in table 2 .

Table 2: The Increasing Score of Students' Recount Text through Reflection Learning Method from Its Organizations with Indicators "Coherence and Spatial Order"

\begin{tabular}{|ccccc|} 
NO & Indicators & \multicolumn{2}{c|}{ The Student' Score } & Increasing \\
& & Cycle I & Cycle II & Cl - CII (\%) \\
\hline $\mathbf{1}$ & Coherence & 5.57 & 8.13 & 45.96 \\
\hline $\mathbf{2}$ & Spatial Order & 5.36 & 8.28 & 54.48 \\
\hline & $\sum \boldsymbol{X}$ & 10.93 & 16.41 & 100.44 \\
\hline & $\bar{X}$ & 5.47 & 8.21 & 50.22 \\
\hline
\end{tabular}

The data of table 2 indicates the students' mean score from organization with indicators "coherence and spatial order" in cycle I are 5.47 and classifying as poor score. Through revision of the lesson plan to be implemented in learning process, the target has been achieved with the mean score over 7.0 that are 8.21 with some corrections of activities in the cycle II. The mean score in data of table 1 achieves by the students in cycle II has been indicated a significant increasing in term of recount text that it $50.22 \%$ from cycle I to cycle II. The increasing of the students' recount text through reflection learning method in the organizations presents at the figure 2 .

Figure 2: The Increasing Score of Students' Recount Text through Reflection Learning Method from Its Organizations

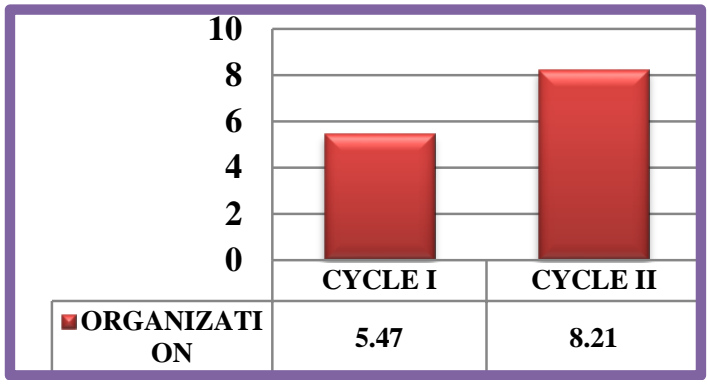

The data of the figure 2 indicates the students' recount text achievement is on the cycle I. The students' recount text achievement in cycle II is higher than cycle I that is $8.21>5.47$. The cycle I means that the score increasing in cycle II, with the increasing from cycle I to cycle II is $50.22 \%$.

c. The Increasing of Students' Recount Text through Reflection Learning Method from Its Generic Structures with Indicators "Orientation, events, and reorientation"

The score of the students' writing skill in recount text for generic structures with 
indicators "orientation, events, and reorientation" indicates that there is increasing between score in cycle I and cycle II after use. The increasing score of students' recount text through reflection learning method from its generic structures shows in table 3 .

Table 3: The Increasing of Students' Recount Text through Reflection Learning Method from Its Generic Structures with Indicators "Orientation, Events, and Reorientation"

\begin{tabular}{|c|c|c|c|c|}
\hline \multirow[t]{2}{*}{ NO } & \multirow[t]{2}{*}{ Indicators } & \multicolumn{2}{|c|}{ The Student' Score } & \multirow{2}{*}{$\begin{array}{l}\text { Increasing } \\
\mathrm{Cl}-\mathrm{Cll}(\%)\end{array}$} \\
\hline & & Cycle I & Cycle II & \\
\hline 1 & Orientation & 5.15 & 8.27 & 60.58 \\
\hline 2 & Events & 5.57 & 7.72 & 38.60 \\
\hline \multirow[t]{2}{*}{3} & $\mathrm{Re}-$ orientation & 5.36 & 8.38 & 56.34 \\
\hline & $\sum x$ & 16.08 & 24.37 & 155.52 \\
\hline \multirow{2}{*}{\multicolumn{2}{|c|}{$\bar{X}$}} & 5.36 & 8.12 & 51.84 \\
\hline & & & \multicolumn{2}{|c|}{ GENERIC STRUCTURES } \\
\hline \multicolumn{3}{|c|}{$\begin{array}{l}\text { The data of table } 3 \text { indicates the students' } \\
\text { mean score from generic structures with } \\
\text { indicators "orientation, events, and } \\
\text { reorientation" in cycle I are } 5.36 \text { and } \\
\text { classifying as poor score. Through revision of } \\
\text { the lesson plan to be implemented in }\end{array}$} & 10 & CYCLE II \\
\hline
\end{tabular}
learning process, the target has been achieved with the mean score over 7.0 that is 8.12 with some corrections of activities in the cycle II. The mean score in data of table 1 achieves by the students in cycle II had been indicated a significant increasing in term of recount text that is $51.84 \%$ from cycle I to cycle II. The increasing of the students' recount text through reflection learning method in the generic structures presents at the figure 3 .

Figure 3: The Increasing of Students' Recount Text through Reflection Learning Method from Its Generic Structures
The data of the figure 3 indicates the students' recount text achievement is on the cycle I. The students' recount text achievement in cycle II is higher than cycle I that is $8.12>5.36$. The cycle I means that the score increasing in cycle II, with the increasing from cycle I to cycle II is $51.84 \%$.

\section{d. The Increasing of Students' Writing Skill through Reflection Learning Method}

The increasing of the students' writing skill in term of contents, organizations, and generic structures through reflection learning method is very good. It is indicated by the mean score of cycle I and cycle II tests which are shown clearly in the table 4. 
Table 4: The Increasing of Students' Writing Skill through Reflection Learning Method

\begin{tabular}{|ccccc|} 
NO & Indicators & \multicolumn{2}{c|}{ The Student' Score } & Increasing \\
\hline $\mathbf{1}$ & Cycle I & Cycle II & Cl - CII (\%) \\
\hline $\mathbf{2}$ & Organization & 5.37 & 7.53 & 40.22 \\
\hline $\mathbf{3}$ & Generic Structures & 5.47 & 8.21 & 50.09 \\
\hline & $\sum X$ & 5.36 & 8.38 & 51.49 \\
\hline & $\bar{X}$ & 16.2 & 23.86 & 141.8 \\
\hline
\end{tabular}

The data of table 4 indicates the students' mean score from contents, organizations, and generic structures in cycle $\mathrm{I}$ is 5.40 and classifying as poor score. Through revision of the lesson plan to be implemented in learning process, the target has been achieved with the mean score over 7.0 that are 7.95 with some corrections of activities in the cycle II. The mean score in data of table 1 achieves by the students in cycle II has been indicated a significant increasing in term of recount text that it $47.27 \%$ from cycle I to cycle II. The increasing of the students' recount text through reflection learning method in the generic structures presents at the figure 4 .

Figure 4: The Increasing of Students' Writing Skill through Reflection Learning Method from Contents, Organizations, and Generic Structures

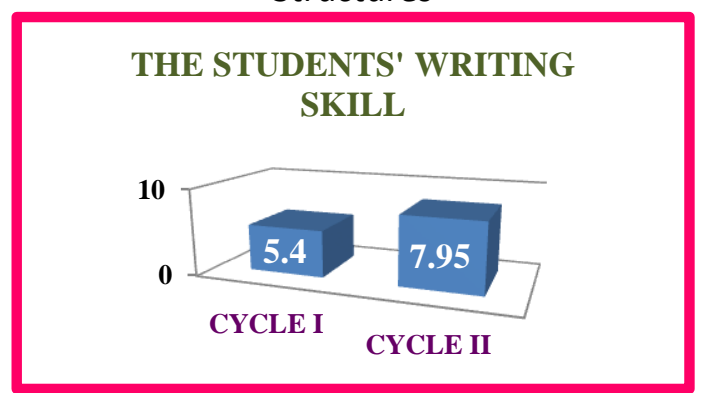

The data of the figure 5 indicates that the students writing skill which are covering content, organization, and generic structures in cycle I is still low 5.40 since there are some students that the content of their writing still lack in setting idea as well as controlling idea, still difficult in determining appropriates tense and the uses of mechanics are due to capitalization, punctuation and spelling not appropriate. Through revision of the lesson plan to be implemented in learning process, the score target has been achieved in cycle I over 7.0 that is 7.95 with some corrections of activities in the cycle II.

\section{DISCUSSIONS}

The discussion covered the interpretation of findings which were derived from the evaluation result about the frequency and rate percentage of the students' cycle I and cycle II tests in writing skill.

a. The Frequency and Rate Percentage of the Students' Scores at Cycle I and Cycle II in Term of Content Covered Unity and Completeness

\section{Unity}

The used of reflection learning method increased the students' writing skill in term of unity could be seen by the differences of the students' score of diagnostic test without reflection learning method and the students' increased after conducting cycle I and cycle II by used reflection learning method in teaching and learning process. We could see the differences of the students' score at the table 5 . 
Table 5: Frequency and Rate Percentage of the Students' Score at Cycle I and Cycle II in Term of Content Covered Unity and Completeness

\begin{tabular}{|ccccccc|} 
No & Classification & Range of Score & \multicolumn{3}{c}{ The Application of RLM } \\
& & & \multicolumn{2}{c|}{ Cycle I } & \multicolumn{2}{c|}{ Cycle II } \\
\cline { 3 - 7 } & & & Freq & $\%$ & Freq & $\%$ \\
\hline 1 & Excellent & $9.0-10$ & 0 & 0 & 2 & 6.06 \\
\hline 2 & Very Good & $8.0-8.9$ & 0 & 0 & 10 & 30.30 \\
\hline 3 & Good & $7.0-7.9$ & 0 & 0 & 0 & 0 \\
\hline 4 & Fair & $6.0-6.9$ & 10 & 30.30 & 16 & 48.48 \\
\hline 5 & Poor & $5.0-5.9$ & 17 & 51.52 & 5 & 15.2 \\
\hline 6. & Very Poor & $0-4.9$ & 6 & 18.18 & 0 & 0 \\
\hline
\end{tabular}

The data of table 5 indicated that frequency and rate percentage in cycle I and cycle II. In cycle I, there were 6 or $18.18 \%$ students who got very poor score, 17 or $51.52 \%$ students who got poor score, and 10 or $30.30 \%$ students who got fair score. In cycle II, there are 5 or $15.2 \%$ students who got poor score, 16 or $48.48 \%$ students who got fair score, 10 or $30.30 \%$ students who got very good score, and 2 or $6.06 \%$ students who got excellent score. Since the data of the table 5 indicated that the frequency and rate percentage in cycle $I I$ is higher than cycle I, it proves that using reflection learning method in learning process is able to increases the students' content in term of unity after has been conducted in action of the cycle I and after making some revisions in cycle II.

\section{Completeness}

The used of reflection learning method increased the students' writing skill in term of completeness could be seen by the differences of the students' score of diagnostic test without reflection learning method and the students' increased after conducting cycle I and cycle II by used reflection learning method in teaching and learning process. We could see the differences of the students' score at the table 6.

Table 6: Frequency and Rate Percentage of the Students' Score at Cycle I and Cycle II in Term of Content Covered Completeness

\begin{tabular}{|cc|ccccc|} 
No & Classification & Range of Score & \multicolumn{3}{c}{ The Application of RLM } \\
& & & \multicolumn{2}{c}{ Cycle I } & \multicolumn{2}{c|}{ Cycle II } \\
\cline { 3 - 7 } & & & Freq & $\%$ & Freq & $\%$ \\
\hline 1 & Excellent & $9.0-10$ & 0 & 0 & 4 & 12.12 \\
\hline 2 & Very Good & $8.0-8.9$ & 0 & 0 & 17 & 51.51 \\
\hline 3 & Good & $7.0-7.9$ & 0 & 0 & 0 & 0 \\
\hline 4 & Fair & $6.0-6.9$ & 15 & 45.45 & 12 & 36.36 \\
\hline 5 & Poor & $5.0-5.9$ & 13 & 39.39 & 0 & 0 \\
\hline 6. & Very Poor & $0-4.9$ & 5 & 15.15 & 0 & 0 \\
\hline
\end{tabular}


The data of table 6 indicated that frequency and rate percentage in cycle I and cycle II. In cycle I, there were 5 or $15.15 \%$ students who got very poor score, 13 or $39.39 \%$ students who got poor score, and 15 or $45.45 \%$ students who got fair score. In cycle II, there are 12 or $36.36 \%$ students who got fair score, 17 or $51.51 \%$ students who got very good score, and 4 or $12.12 \%$ students who got excellent score. Since the data of the table 6 indicated that the frequency and rate percentage in cycle $I I$ is higher than cycle I, it proves that using reflection learning method in learning process is able to increases the students' content in term of completeness after has been conducted in action of the cycle I and after making some revisions in cycle II. b. The Frequency and Rate Percentage of the Students' Scores at Cycle I and Cycle II in Term of Organization Covered Coherence and Spatial Order

\section{Coherence}

The used of reflection learning method increased the students' writing skill in term of coherence could be seen by the differences of the students' score of diagnostic test without reflection learning method and the students' increased after conducting cycle I and cycle II by used reflection learning method in teaching and learning process. We could see the differences of the students' score at the table 7.

Table 7: Frequency and Rate Percentage of the Students' Score at Cycle I and Cycle II in Term of Organization Covered Coherence

\begin{tabular}{|ccccccc|} 
No & Classification & $\begin{array}{c}\text { Range of } \\
\text { Score }\end{array}$ & \multicolumn{3}{c}{ The Application of RLM } \\
& & & Freq & $\%$ & Freq & Cycle II \\
\hline 1 & Excellent & $9.0-10$ & 0 & 0 & 7 & 21.21 \\
\hline 2 & Very Good & $8.0-8.9$ & 0 & 0 & 15 & 45.45 \\
\hline 3 & Good & $7.0-7.9$ & 0 & 0 & 0 & 0 \\
\hline 4 & Fair & $6.0-6.9$ & 15 & 45.45 & 11 & 33.33 \\
\hline 5 & Poor & $5.0-5.9$ & 14 & 42.42 & 0 & 0 \\
\hline 6. & Very Poor & $0-4.9$ & 4 & 12.12 & 0 & 0 \\
\hline
\end{tabular}

The data of table 7 indicated that frequency and rate percentage in cycle I and cycle II. In cycle I, there were 4 or $12.12 \%$ students who got very poor score, 14 or $42.42 \%$ students who got poor score, and 15 or $45.45 \%$ students who got fair score. In cycle II, there are 11 or $33.33 \%$ students who got fair score, 15 or $45.45 \%$ students who got very good score, and 7 or $21.21 \%$ students who got excellent score. Since the data of the table 7 indicated that the frequency and rate percentage in cycle $I I$ is higher than cycle I, it proves that using reflection learning method in learning process is able to increases the students' organization in term of coherence after has been conducted in action of the cycle I and after making some revisions in cycle II.

\section{Spatial Order}

The used of reflection learning method increased the students' writing skill in term of spatial order could be seen by the differences of the students' score of diagnostic test without reflection learning method and the students' increased after conducting cycle I and cycle II by used reflection learning method in teaching and learning process. We could see the 
differences of the students' score at the table 8 .

Table 8: Frequency and Rate Percentage of the Students' Score at Cycle I and Cycle II in Term of Organization Covered Spatial Order

\begin{tabular}{|c|c|c|c|c|c|c|}
\hline \multirow[t]{3}{*}{ No } & \multirow[t]{3}{*}{ Classification } & \multirow{3}{*}{$\begin{array}{l}\text { Range of } \\
\text { Score }\end{array}$} & \multicolumn{4}{|c|}{ The Application of RLM } \\
\hline & & & \multicolumn{2}{|c|}{ Cycle I } & \multicolumn{2}{|c|}{ Cycle II } \\
\hline & & & Freq & $\%$ & Freq & $\%$ \\
\hline 1 & Excellent & $9.0-10$ & 0 & 0 & 9 & 27.27 \\
\hline 2 & Very Good & $8.0-8.9$ & 0 & 0 & 15 & 45.45 \\
\hline 3 & Good & $7.0-7.9$ & 0 & 0 & 0 & 0 \\
\hline 4 & Fair & $6.0-6.9$ & 13 & 39.39 & 8 & 24.24 \\
\hline 5 & Poor & $5.0-5.9$ & 14 & 42.42 & 1 & 3.03 \\
\hline 6. & Very Poor & $0-4.9$ & 6 & 18.18 & 0 & 0 \\
\hline
\end{tabular}

The data of table 8 indicated that frequency and rate percentage in cycle I and cycle II. In cycle I, there were 6 or $18.18 \%$ students who got very poor score, 14 or $42.42 \%$ students who got poor score, and 13 or $39.39 \%$ students who got fair score. In cycle II, there are 1 or $3.03 \%$ students who got poor score, 8 or $24.24 \%$ students who got fair score, 15 or $45.45 \%$ students who got very good score, and 9 or $27.27 \%$ students who got excellent score. Since the data of the table 8 indicated that the frequency and rate percentage in cycle $I I$ is higher than cycle I, it proves that using reflection learning method in learning process is able to increases the students' organization in term of spatial order after has been conducted in action of the cycle I and after making some revisions in cycle II. c. The Frequency and Rate Percentage of the Students' Scores at Cycle I and Cycle II in Term of Generic Structures Covered Orientation, Events, and Reorientation

\section{Orientation}

The used of reflection learning method increased the students' writing skill in term of orientation could be seen by the differences of the students' score of diagnostic test without reflection learning method and the students' increased after conducting cycle I and cycle II by used reflection learning method in teaching and learning process. We could see the differences of the students' score at the table 9. 
Table 9: Frequency and Rate Percentage of the Students' Score at Cycle I and Cycle II in Term of Generic Structures Covered Orientation

\begin{tabular}{|ccccccc|} 
No & Classification & Range of Score & \multicolumn{3}{c}{ The Application of RLM } \\
& & & \multicolumn{2}{c|}{ Cycle I } & \multicolumn{2}{c|}{ Cycle II } \\
\hline & & & Freq & $\%$ & Freq & $\%$ \\
\hline 1 & Excellent & $9.0-10$ & 0 & 0 & 8 & 24.24 \\
\hline 2 & Very Good & $8.0-8.9$ & 0 & 0 & 17 & 51.51 \\
\hline 3 & Good & $7.0-7.9$ & 0 & 0 & 0 & 0 \\
\hline 4 & Fair & $6.0-6.9$ & 9 & 27.27 & 7 & 21.21 \\
\hline 5 & Poor & $5.0-5.9$ & 18 & 54.54 & 1 & 3.03 \\
\hline 6. & Very Poor & $0-4.9$ & 6 & 18.18 & 0 & 0 \\
\hline
\end{tabular}

The data of table 9 indicated that frequency and rate percentage in cycle I and cycle II. In cycle I, there were 6 or $18.18 \%$ students who got very poor score, 18 or $53.53 \%$ students who got poor score, and 9 or $27.27 \%$ students who got fair score. In cycle II, there are 1 or $3.03 \%$ students who got poor score, 7 or $21.21 \%$ students who got fair score, 17 or $51.51 \%$ students who got very good score, and 8 or $24.24 \%$ students who got excellent score. Since the data of the table 8 indicated that the frequency and rate percentage in cycle II is higher than cycle I, it proves that using reflection learning method in learning process is able to increases the students' generic structures in term of orientation after has been conducted in action of the cycle I and after making some revisions in cycle II.

\section{Events}

The used of reflection learning method increased the students' writing skill in term of events could be seen by the differences of the students' score of diagnostic test without reflection learning method and the students' increased after conducting cycle I and cycle II by used reflection learning method in teaching and learning process. We could see the differences of the students' score at the table 10.

Table 10: Frequency and Rate Percentage of the Students' Score at Cycle I and Cycle II in Term of Generic Structures Covered Events

\begin{tabular}{|ccccccc|} 
No & Classification & $\begin{array}{c}\text { Range of } \\
\text { Score }\end{array}$ & \multicolumn{3}{c|}{ The Application of RLM } \\
& & & \multicolumn{2}{c|}{ Cycle I } & \multicolumn{2}{c|}{ Cycle II } \\
\hline 1 & Excellent & $9.0-10$ & 0 & 0 & 4 & 12.12 \\
\hline 2 & Very Good & $8.0-8.9$ & 0 & 0 & 15 & 45.45 \\
\hline 3 & Good & $7.0-7.9$ & 0 & 0 & 0 & 0 \\
\hline 4 & Fair & $6.0-6.9$ & 14 & 42.42 & 12 & 36.36 \\
\hline 5 & Poor & $5.0-5.9$ & 16 & 48.48 & 2 & 6.06 \\
\hline 6. & Very Poor & $0-4.9$ & 3 & 9.09 & 0 & 0 \\
\hline
\end{tabular}


The data of table 10 indicated that frequency and rate percentage in cycle I and cycle II. In cycle I, there were 3 or $9.09 \%$ students who got very poor score, 16 or $48.48 \%$ students who got poor score, and 14 or $42.42 \%$ students who got fair score. In cycle II, there are 2 or $6.06 \%$ students who got poor score, 12 or $36.36 \%$ students who got fair score, 15 or $45.45 \%$ students who got very good score, and 4 or $12.12 \%$ students who got excellent score. Since the data of the table 8 indicated that the frequency and rate percentage in cycle $I I$ is higher than cycle I, it proves that using reflection learning method in learning process is able to increases the students' generic structures in term of events after has been conducted in action of the cycle I and after making some revisions in cycle II.

\section{Reorientation}

The used of reflection learning method increased the students' writing skill in term of events could be seen by the differences of the students' score of diagnostic test without reflection learning method and the students' increased after conducting cycle I and cycle II by used reflection learning method in teaching and learning process. We could see the differences of the students' score at the table 11.

Table 11: Frequency and Rate Percentage of the Students' Score at Cycle I and Cycle II in Term of Generic Structures Covered Re-Orientation

\begin{tabular}{|ccccccc|} 
No & Classification & Range of Score & \multicolumn{3}{c}{ The Application of RLM } \\
& & & \multicolumn{2}{c}{ Cycle I } & \multicolumn{2}{c|}{ Cycle II } \\
\cline { 3 - 7 } & & Freq & $\%$ & Freq & $\%$ \\
\hline 1 & Excellent & $9.0-10$ & 0 & 0 & 10 & 30.30 \\
\hline 2 & Very Good & $8.0-8.9$ & 0 & 0 & 15 & 45.45 \\
\hline 3 & Good & $7.0-7.9$ & 0 & 0 & 0 & 0 \\
\hline 4 & Fair & $6.0-6.9$ & 1 & 3.03 & 17 & 51.51 \\
\hline 5 & Poor & $5.0-5.9$ & 18 & 54.54 & 1 & 3.03 \\
\hline 6. & Very Poor & $0-4.9$ & 4 & 12.12 & 0 & 0 \\
\hline
\end{tabular}

The data of table 11 indicated that frequency and rate percentage in cycle I and cycle II. In cycle I, there were 4 or $12.12 \%$ students who got very poor score, 18 or $54.54 \%$ students who got poor score, and 1 or $3.03 \%$ students who got fair score. In cycle II, there were 1 or $3.03 \%$ students who got poor score, 17 or $51.51 \%$ students who got fair score, 15 or $45.45 \%$ students who got very good score, and 10 or $30.30 \%$ students who got excellent score. Since the data of the table 8 indicated that the frequency and rate percentage in cycle $I I$ is higher than cycle I, it proves that using reflection learning method in learning process is able to increases the students' generic structures in term of re-orientation after has been conducted in action of the cycle I and after making some revisions in cycle II.

Based on the data which was collected from cycle I and cycle II test score, it indicated the students' writing skill score through reflection learning method at class $X$. Language program students of SMA Negeri 2 Sungguminasa Gowa regency was better 
than before through reflection learning method in diagnostic test and effective in classroom action research (CAR). Whereas, cycle II mean score was greater than cycle 1 and diagnostic test $(7.95>5.40>2.31)$ which was supported by significant increased 47.27 $\%$ from cycle I to cycle II.

\section{CONCLUSION}

Reflection learning method could increase the writing skill of the first grade students' of SMA Negeri 2 Sungguminasa Gowa regency. It was proven by the based on the data which was collected from cycle I and cycle II test score, it indicated the students' writing skill score through reflection learning method at class $X$ of SMA Negeri 2 Sungguminasa Gowa regency was better than before through reflection learning method in diagnostic test and effective in classroom action research. Whereas, cycle II mean score was greater than cycle 1 and diagnostic test (7.95 > 5.40 $>2.31$ ) which was supported by significant increased $47.27 \%$ from cycle I to cycle II. Finally the writer concluded that through reflection learning method could increase the students writing skill covered recount text with the significant increased was 47.27 $\%$.

\section{Suggestion}

Based on the conclusion above, the writer gives some suggestions as follow: 1 ). It is suggested for the English teacher of SMA Negeri 2 Sungguminasa Gowa regency to apply or to use the reflection learning method one alternative way in their teaching and learning process especially in teaching and learning writing process. The teaching and learning writing process should enhance students' writing skill. 2). The English teacher of SMA Negeri 2 Sungguminasa Gowa regency should invite and raise the students' learning motivation by manipulating various methods in presenting productive skill, include writing skill, in other hand, the English teacher of SMA Negeri 2 Sungguminasa Gowa regency should create the fun atmosphere when they used reflection learning method or studied at classroom, so with fun atmosphere the students enjoy learning writing activity. 3). It is suggested for the students of SMA Negeri 2 Sungguminasa Gowa regency that they should be active in their reading activity so they can be easy to increase their writing skill.

\section{REFERENCES}

[1] Andrew. 2017. Developing Writing Strategies in the Foreign Language Classroom. Unpublished. Thesis of English Studies at University of Almeria.

[2] Crishtopher. 2017. Writing and Reflection. London : Kogan Page.

[3] Cumming. 2016. Teaching Writing Skill. Amsterdam: John Benjamins Publishing Company.

[4] Derewianka. 2015. Increasing the Students' Proficiency in Writing Skill at SMAN. 1. Makassar. Thesis. FKIP UNM Makassar.

[5] Djuharie. 2017. Writing Recount Paragraph. Oxford: oxford University Press.

[6] Foo. 2016. Creative English Workbook. Jakarta: Erlangga.

[7] Gay. 2016. Educational Research: Competencies for Analysis and Application. Ohio : Charlea. E.Merril Publishing CompanySecond Edition Practice. Hall. Inc. 
[8] Harmer. 2017. The Practice of English Language Teaching. New Edition. London: Longman. Inc.

[9] Ismail,. Jabri, U. (2017). Is it Application of Extended Writing Truly Push Writing Student Ability? Jurnal Pendidikan Edumaspul, 1(1), 1-14.

[10] Ismail, I. U. J. R. M. (2017). International Conference on Education (ICE), Strengthening Education Literacy for Global Competitiveness. In U. M. P. Nuning Cahyaningrum (Ed.), Rubrics-Based Assessment as a Teaching Strategy of Writing Journal for Novice Authors (pp. 1-11). Purworejo: Universitas Muhammadiyah Purworejo. Retrieved from

http://eproceedings.umpwr.ac.id/ind ex.php/ice/issue/view/5/showToc

[11] Keogh and Walker. 2016. Reflection: Turning Experience Into. London:Longman.

[12] Lockhart. 2016. Reflective Teaching in Second Language Classrooms. New York : Cambridge University Press.

[13] McMahan and Elizabeth. 1996. Literature and Writing Process. New Jersey: Prentice- all
[14] Oshima. 2016. Reflection in learning \& professional Development: Theory and practice. New York. Cambridge University Press.

[15] Oshima. 2016. Introduction to Academic Writing. London and New York:Longman Group. UK.Limited.

[16] Smith. 2017. Writing Recount Paragraph. Oxford: oxford University Press.

[17] Virgina. 2016. Writing Rubric. Cambridge: Cambridge University Press.

[18] Weigle. 2016. Assessing Writing. Cambridge: Cambridge University Press.

[19] Zubizarreta. 2016. The Learning Portfolio: Reflective Practice for Improving

Student Learning, Second Edition. Jos sey-Bass 